\title{
The nutritional value and quality of squid (Illex illecebrosus) meal as source of dietary protein for broiler chicken*
}

\author{
BY H. W. HULAN AND F. G. PROUDFOOT \\ Agriculture Canada, Research Station, Kentville, \\ Nova Scotia, $B_{4} N_{\text {I }} J_{5}$ Canada \\ AND C. G. ZARKADAS \\ Food Research Institute, Research Branch, Agriculture Canada, \\ Ottawa, Ontario, KI A oC6 Canada \\ (Received 9 June 1978 - Accepted 29 June 1978)
}

1. Squid meal (SqM), produced by grinding and drying the whole squid (Illex illecebrosus) common to the northeast Atlantic and Mediterranean, contained $645 \mathrm{~g}$ protein $/ \mathrm{kg}$ and appeared limiting with respect to lysine, methionine and cystine.

2. Although a comparison of the essential amino acid profiles of $\mathrm{SqM}$ with other protein concentrates indicated that $\mathrm{SqM}$ was higher than fish meal and soya-bean meal but lower than casein or whole-egg protein, these tests could not accurately predict protein quality.

3. A new approach is reported for evaluating protein quality of SqM. It was based on the direct chromatographic determination of its collagen content, from the amounts of 5-hydroxylysine or 5-hydroxyproline present, and elastin, from the amounts of desmosine or iso-desmosine present. This method can alsobe routinely used to assess the connective tissue content and protein quality of animal protein supplements such as fish, meat-and-bone meals.

4. A nutritional evaluation of SqM as a source of protein for poultry was carried out using 320 male and 320 female Cobb chicks fed from I-d-old to $48 \mathrm{~d}$, a control diet containing $50 \mathrm{~g} / \mathrm{kg}$ fish meal or test diets containing $50 \mathrm{~g}, 100 \mathrm{~g}$ or $150 \mathrm{~g} \mathrm{SqM} / \mathrm{kg}$.

5. Feeding of SqM at a rate of up to $100 \mathrm{~g} / \mathrm{kg}$ diet resulted in optimum biological response and monetary returns.

Squid, the popular name given to a large number of cephalopod molluscs is a largely untapped protein resource of the oceans of great economic potential (Clarke, 1966) which could be used in both human and animal diets. The traditional Newfoundland bait squid Illex illecebrosus (Templeman, I966), although somewhat sporadic in occurrence, has become quite plentiful in recent years probably because its main use as fish bait has been greatly reduced. In spite of its abundance, much concerning the nutritive value and protein quality of squid meal (SqM) is unknown.

The nutritive and economic potential of meal produced from whole squid as a dietary protein supplement in chicken broiler diets prompted the present study. The purpose of this investigation was to assess the nutritional value and protein quality of the SqM, using the broiler chicken. Thus, the effect of adding SqM to the diet on growth response, food conversion and mortality of broiler chickens was measured. The experiment was also designed to establish the optimum level of SqM supplementation to practical broiler starter and finisher diets. An attempt was also made to relate the protein quality of the SqM to its nutritive value by standard predictive tests based on its amino acid composition and by the direct determination of its connective tissue and skeletal muscle content by chromatographic methods developed recently by Zarkadas (I975) and C. G. Zarkadas (unpublished results).

* Contribution no. 1644 from Research Station, Kentville, Nova Scotia, and contribution no. 353 from the Food Research Institute, Ottawa. 


\section{EXPERIMENTAL}

\section{Materials}

The Beckman type AA-20 or type W-2 resin, equivalent to Durrum type DC-6A II $\cdot 0 \pm$ $\mathrm{I} \cdot \mathrm{O} \mu \mathrm{m}$ spherical resin, was purchased from Beckman Instruments Inc., Palo Alto, California, USA. Most of the unusual amino acids employed for the preparation of the amino acid standard calibration mixture were prepared as described previously (Zarkadas, 1975). Desmosine and isodesmosine were isolated from bovine Ligamentum nuchae elastin by the manual method described previously (Zarkadas, 1975). All other chemicals and reagents were of the highest purity commercially available and were used without further purification.

Each of the protein concentrates and cereals used in these studies was purchased from ordinary commercial sources. SqM for use in the basal diets was obtained from National Sea Products Ltd, Halifax, Nova Scotia, in I $t$ quantities. Batches of this material were thoroughly mixed before samples were taken for both chemical analyses and animal experiments.

\section{Analytical methods}

Standard methods for moisture, total ash, sodium chloride, calcium, phosphorus and crude protein (nitrogen $\times 6.25$; $\mathrm{N}$ content determined by the Kjeldahl method) were followed as outlined by the Association of Official Agricultural Chemists (1975).

Total lipids were extracted and determined as described earlier (Hulan et al. 1976) and crude fat was determined as described by Crampton (1956). True metabolizable energy (TME) was determined by the method of Sibbald (1976).

\section{Procedures for amino acid analyses}

Standard amino acid analyses were carried out on a Beckman Spinco Model I 2 M fullyautomated micro-column amino acid analyser (Beckman Instruments Inc., 1976). The instrument was equipped with a module control (Autolab Spectra-Physics GmbH, 61 Darmstadt, West Germany) and a companion Autolab System AA (Beckman Instruments Inc., 1976). Triplicate SqM samples were hydrolysed under reduced pressure in constant boiling $6 \mathrm{M}$-hydrochloric acid at $110^{\circ}$ for $24,48,72$ and $96 \mathrm{~h}$ with the precautions described by Moore \& Stein (1963). Analyses of individual acid-hydrolysates were performed in triplicate by methods previously described (Hidiroglou \& Zarkadas, 1976).

4-Hydroxyproline was determined separately from concentrated hydrolysates (equivalent to $0.2-0.3 \mathrm{mg}$ per column) by a modified method (Beckman Instruments Inc., 1976) using a single micro-column $(330 \times 2.8 \mathrm{~mm})$ packed with Beckman type AA-20 resin. This column was eluted by a single buffer containing $0.24 \mathrm{M}$-lithium, $0 \cdot 16 \mathrm{M}$-citrate thiodiglycol $(250 \mathrm{~g} / \mathrm{l} ; \mathrm{ro} \mathrm{ml} / \mathrm{l})$, ethanol ( $\mathrm{IO} \mathrm{ml} / \mathrm{l})$, octanoic acid $(0 \cdot \mathrm{I} \mathrm{ml} / \mathrm{l})$ and phenol $(\mathrm{I} \cdot 0 \mathrm{~g} / \mathrm{l})$ which was adjusted to $\mathrm{pH} 2 \cdot 85 \pm 0.01$ at $25^{\circ}$. In this system, aspartic acid and 4 -hydroxyproline were completely separated and emerged from the micro-column at 36.8 and $4 \mathrm{I} \cdot 8 \mathrm{~min}$ respectively. Similarly, taurine, was analysed by this system, and methionine and cysteine were determined in separate samples as their oxidation products by the performic acid procedure of Moore (1963).

The determination of all methylated basic amino acids, the diastereoisomers of 5 -hydroxylysine, stable cross-links and related compounds in collagen and elastin were carried out with concentrated acid-hydrolysates (equivalent to 3-5 $\mathrm{mg}$ protein), either by the manual chromatographic method or by the accelerated single-micro-column $(550 \times 2.8 \mathrm{~mm})$ system described previously (Zarkadas, 1975 and C. G. Zarkadas, unpublished results), so that peaks adequate for these components could be obtained. 
Table I. Composition $(\mathrm{g} / \mathrm{kg})$ of the experimental diets

\begin{tabular}{|c|c|c|c|c|c|c|c|c|}
\hline \multirow[b]{2}{*}{ Ingredient } & \multicolumn{4}{|c|}{ Starter diets } & \multicolumn{4}{|c|}{ Finisher diets } \\
\hline & I & 2 & 3 & 4 & I & 2 & 3 & 4 \\
\hline Ground maize & 450 & 444 & 459 & 475 & 580 & 580 & 585 & 570 \\
\hline Ground wheat & 160 & 160 & 160 & 160 & 220 & 220 & 220 & 220 \\
\hline Soya-bean meal $(490 \mathrm{~g} / \mathrm{kg})$ & 295 & 295 & 232 & 167 & 94 & 87 & 35 & - \\
\hline Fish meal $(630 \mathrm{~g} / \mathrm{kg})$ & 50 & - & - & - & 50 & - & - & - \\
\hline $\begin{array}{l}\text { Squid (Illex illecebrosus) } \\
\text { meal }(640 \mathrm{~g} / \mathrm{kg})\end{array}$ & - & 50 & 100 & 150 & - & 50 & 100 & 150 \\
\hline Poultry grease & 20 & 20 & 20 & 20 & 30 & 30 & 30 & 30 \\
\hline Ground limestone & 9 & 15 & 13 & 12 & 8 & 15 & 14 & I3 \\
\hline Dicalcium phosphate & 6 & 6 & 6 & 6 & 8 & 8 & 6 & 7 \\
\hline Iodized salt & 5 & 5 & 5 & 5 & 5 & 5 & 5 & 5 \\
\hline Vitamin mineral premix & 5 & 5 & 5 & 5 & 5 & 5 & 5 & 5 \\
\hline \multicolumn{9}{|l|}{ Calculated analyses: } \\
\hline $\mathrm{ME}(\mathrm{MJ} / \mathrm{kg})$ & $12 \cdot 56$ & $12 \cdot 43$ & 12.60 & $12 \cdot 56$ & 13.46 & $13 \cdot 35$ & I3.4I & 13.6 \\
\hline Protein $(\mathrm{g} / \mathrm{kg})$ & $237^{\circ}$ & 236 & 238 & 239 & 158 & 155 & 160 & 162 \\
\hline
\end{tabular}

$\mathrm{ME}$, metabolizable energy.

* Supplied $(/ \mathrm{kg}$ diet): $3096 \mu \mathrm{g}$ retinyl palmitate; 32.50 $\mu \mathrm{g} \mathrm{D} ; 5 \mathrm{mg}$ riboflavin; I I mg Ca-D pantothenate; I0 $\mu \mathrm{g}$ cyanocobolamin; $24 \mathrm{mg}$ nicotinic acid; $1.5 \mathrm{mg}$ menaphthone; $0.8 \mathrm{mg}$ folic acid; I2. $\mathrm{mg} \mathrm{mL}-\alpha-$ tocopherol; $4.4 \mathrm{mg}$ procaine penicillin; $749 \mathrm{mg}$ Amprol High E (250 g/kg) (Merk, Sharp and Dohme, Canada Ltd., Toronto); $450 \mathrm{mg}$ DL-methionine; I $12 \mathrm{mg}$ manganous oxide $(600 \mathrm{~g} / \mathrm{kg}) ; 83 \mathrm{mg}$ zinc oxide $(720 \mathrm{~g} / \mathrm{kg}) ; 20 \mathrm{mg}$ copper sulphate $(250 \mathrm{~g} / \mathrm{kg}) ; 219 \mu \mathrm{g}$ sodium selenate; $200 \mathrm{mg}$ ethoxyquin; enough ground maize to make to $5 \mathrm{~g}$.

\section{Animals and diets}

An experiment was carried out using 320 male and 320 female Cobb chicks to evaluate SqM as a source of dietary protein for broilers. Chicks ( $40 \mathrm{~d}$-old) from each sex were randomly selected, housed in each of eight pens (floor area $7.4 \mathrm{~m}^{2}$ ), and grown to slaughter age. Starter diets were fed as crumbles while the finisher diets were fed as pellets. Food and water were given ad lib. The composition of the diets used is presented in Table I. Both starter and finisher diets consisted of a mixture of ground maize, ground wheat, soya-bean meal (SB) with the appropriate additions of either fish meal (FM) or SqM in addition to vitamins and minerals.

The starter and finisher control diets contained $50 \mathrm{~g} \mathrm{FM} / \mathrm{kg}$ diet while FM was substituted with 50 , I00 and $150 \mathrm{~g} \mathrm{SqM} / \mathrm{kg}$ in the three test diets respectively. Appropriate adjustments were made in the levels of maize, SB, limestone and dicalcium phosphate.

\section{Biological traits}

Mortality, male and female live weights at the point the birds were switched from starter to finisher diets $(28 \mathrm{~d})$, and at slaughter $(48 \mathrm{~d})$, and food conversion were determined. Monetary returns from meat marketed over the cost of chicks started and food (based on local producer prices) were calculated.

\section{Statistical analysis}

Orthogonal comparisons of means from each treatment with that of the control were carried out on all of the values obtained (Steel \& Torrie, I960).

\section{RESULTS}

The composition of the SqM currently available on the Atlantic Coast in Canada is given in Table 2. The crude protein content of SqM $(645 \mathrm{~g} / \mathrm{kg})$ was comparable to that of FM $(630 \mathrm{~g} / \mathrm{kg})$ but is much higher than that of $\mathrm{SB}(490 \mathrm{~g} / \mathrm{kg})$. Similarly, the values obtained 
Table 2. Proximate composition $(\mathrm{g} / \mathrm{kg})$ and true metabolizable energy $(T M E)$ of squid (Illex illecebrosus) meal

(Mean values with standard deviations for five determinations)

$\begin{array}{lrc} & \text { Mean } & \text { SD } \\ \text { Moisture } & 67.4 & 0.158 \\ \text { Total nitrogen } & 103.2 & 0.097 \\ \text { Crude protein }(\mathrm{N} \times 6.25) & 645.0 & 0.086 \\ \text { Total lipid } & & \\ \text { Chloroform-methanol extract } & 108.0 & 0.021 \\ \text { Diethyl ether extract } & 120.1 & 0.086 \\ \text { Total ash } & 188.3 & 0.053 \\ \text { NaCl } & 6.6 & 0.01 \mathrm{I} \\ \text { Calcium } & 22.8 & 0.017 \\ \text { Phosphorus } & 32.0 & 0.069 \\ \text { TME (MJ/kg DM)* } & 17.29 & \end{array}$

DM, dry matter.

* TME value for two determinations.

Table 3. Lipid composition $(\mathrm{g} / \mathrm{kg}$ ) of squid (Illex illecebrosus) meal

\begin{tabular}{|c|c|c|c|c|}
\hline \multirow[b]{2}{*}{ Fatty acid } & \multirow[b]{2}{*}{ Total lipid } & \multicolumn{3}{|c|}{ Lipid classes* } \\
\hline & & Triglycerides & $\begin{array}{c}\text { Free } \\
\text { fatty acids }\end{array}$ & Steryl esters \\
\hline $14: 0$ & $3 \cdot 8$ & $5 \cdot 5$ & $4 \cdot 4$ & $3 \cdot 3$ \\
\hline I 6:0 & 23.4 & 15.7 & $4 I \cdot 4$ & $30 \cdot 6$ \\
\hline I6: I & $8 \cdot 5$ & 10.2 & $6 \cdot I$ & $6 \cdot 5$ \\
\hline I 8:0 & $4 \%$ & $3 \cdot 7$ & $8 \cdot 3$ & $4 \cdot 7$ \\
\hline I 8: I & $17 \cdot 3$ & $19 \cdot 3$ & $13 \cdot 5$ & $18 \cdot I$ \\
\hline I $8: 2$ & $\mathrm{I} \cdot \mathrm{O}$ & 0.5 & $\mathrm{I} \cdot \mathrm{O}$ & $4 \cdot 0$ \\
\hline $18: 3$ & $0 \cdot I$ & 0.5 & 0.1 & nd \\
\hline $20: 0$ & $0 . I$ & nd & $0 . I$ & nd \\
\hline $20: I$ & $15 \cdot I$ & $20 \cdot 1$ & 10.8 & 8.9 \\
\hline $20: 4$ & 0.7 & nd & 0.6 & nd \\
\hline $22: 0$ & nd & nd & $O \cdot I$ & 0.7 \\
\hline $22: 1$ & $18 \cdot 2$ & $23 \cdot 6$ & $8 \cdot 3$ & $13 \cdot 9$ \\
\hline $22: 4 n-6$ & 0.1 & 0.3 & 0.1 & nd \\
\hline $22: 6 n-3$ & 4.7 & 0.5 & 0.6 & 0.6 \\
\hline $24: I$ & $I \cdot I$ & 0.2 & $2 \cdot 5$ & $6 \cdot 4$ \\
\hline
\end{tabular}

nd, Not detected.

* Fatty acids are designated by number of carbon atoms : number of double bonds. $n$ represents the number of $\mathrm{C}$ atoms between the terminal double bond and the methyl end of the molecule.

for moisture, total ash, salt $(\mathrm{NaCl})$ and $\mathrm{P}$ are comparable to those reported for $\mathrm{FM}$ by Hubbell (1977). Since the anatomical features of the squid mantle include only a thin, noncalcified, chitinous skeletal element called the pen, its Ca content is considerably lower than that of fish which have a well-defined skeletal structure. Similarly, the total ash content of Illex mantle is $52 \mathrm{~g} / \mathrm{kg}$ dry matter (DM) (Pikkarainen et al. I968) compared to the value reported for whole squid in Table 4 .

$\mathrm{SqM}$, however, has a fairly high content of lipid material ( $108 \mathrm{~g} / \mathrm{kg}$ ) compared to that of FM $(20 \mathrm{~g} / \mathrm{kg})$ and is more comparable to herring meal $(80 / 100 \mathrm{~g} / \mathrm{kg})$. Table 2 shows the crude fat content of SqM determined by the diethyl ether extraction procedure normally employed for the determination of the fat content of a foodstuff (Crampton, 1956). For comparison, the total lipid content determined by the chloroform-methanol extraction 
Table 4. Composition $(\mathrm{g} / \mathrm{kg}$ ) of squid (Illex illecebrosus) meal

(Mean values with standard errors)

\begin{tabular}{|c|c|c|}
\hline & Mean & SD \\
\hline \multicolumn{3}{|l|}{ Amino acid } \\
\hline Phenylalanine* & $10 \cdot 23$ & O. I I \\
\hline Tyrosine & $8 \cdot 39$ & 0.10 \\
\hline Histidine* & $5 \cdot 84$ & 0.18 \\
\hline Isoleucine* & $19 \cdot 27$ & 0.05 \\
\hline Leucine* & 30.66 & 0.03 \\
\hline Methionine* & $13.23 \dagger$ & 0.08 \\
\hline Cystine & $3.35 t$ & 0.16 \\
\hline Valine* & $28 \cdot 66$ & 0.03 \\
\hline Arginine* & $14 \cdot 56$ & 0.07 \\
\hline Lysine* & 25.09 & 0.04 \\
\hline Threonine* & $26 \cdot 38$ & 0.05 \\
\hline Tryptophan* & $9 \cdot 68$ & \\
\hline Total essential amino acids & 195.34 & \\
\hline Aspartic acid & $41 \cdot 6$ & 0.03 \\
\hline Glutamic acid & $43 \cdot 25$ & 0.02 \\
\hline Serine & $38 \cdot 12$ & 0.05 \\
\hline Glycine & $43 \cdot 25$ & 0.02 \\
\hline Alanine & $59 \cdot 88$ & 0.02 \\
\hline Proline & $26 \cdot 74$ & 0.04 \\
\hline \multicolumn{3}{|l|}{ Unusual amino acids $(\mathrm{mg} / \mathrm{kg})$} \\
\hline 4-Hydroxyproline & $429 \cdot 9$ & \\
\hline 5-Hydroxylysine & $75 \cdot 4$ & \\
\hline Isodesmosine & $1 \cdot 4$ & \\
\hline $\mathrm{N}^{\theta}$-methyllysine & 0.8 & \\
\hline $\mathrm{N}^{\tau}$-methylhistidine & $8 \cdot 0$ & \\
\hline Taurine & $49 \cdot 0$ & \\
\hline Total amino acids & $456 \cdot 9$ & \\
\hline Ammonia & $138 \cdot 0$ & \\
\hline Recovery by weight $(\mathrm{g} / \mathrm{kg})$ & $708 \cdot 0$ & \\
\hline
\end{tabular}

procedure of Bligh \& Dyer (1959) is also given in Table 2. The major fatty acids of the lipid component of SqM (Table 3) are: 16:0, I6:I, I8:0, I8:I, 20: I, and 22: I. Higher values for these fatty acids were also obtained in the triglyceride, free fatty acids, and steryl ester fractions (Table 3 ). Since a relatively high FFA content was found in SqM lipid, it is possible that the high levels of FFA were the product of autolysis of lipids before processing (Christie, 1973).

TME (I $7.29 \mathrm{MJ} / \mathrm{kg} \mathrm{DM})$ is considerably higher than the apparent metabolizable energy values (10.77 MJ/kg) reported for FM by Hubbell (1977). The higher metabolizable energy content of SqM can most likely be attributed Ito the higher lipid content of this product (Table 2).

A summary of the amino acid composition of SqM and related analytical values are presented in Table 4, and represents the average values from 24, 48, 72 and $96 \mathrm{~h}$ hydrolysis. The values reported for serine, threonine and tyrosine in Table 4 represent the average of the values extrapolated to zero time of hydrolysis. The values for valine are also the average of values obtained from 72 and $96 \mathrm{~h}$ hydrolysis. The high proline levels found in SqM are in reasonable agreement with those reported by Hochachka et al. (1975), who have suggested that large amounts of free proline are found in the squid mantle which may be coupled with glucose as a high energy source in the squid muscle basal metabolism. The only other 


\section{I68 H. W. Hulan, F. G. Proudfoot and C. G. Zarkadas}

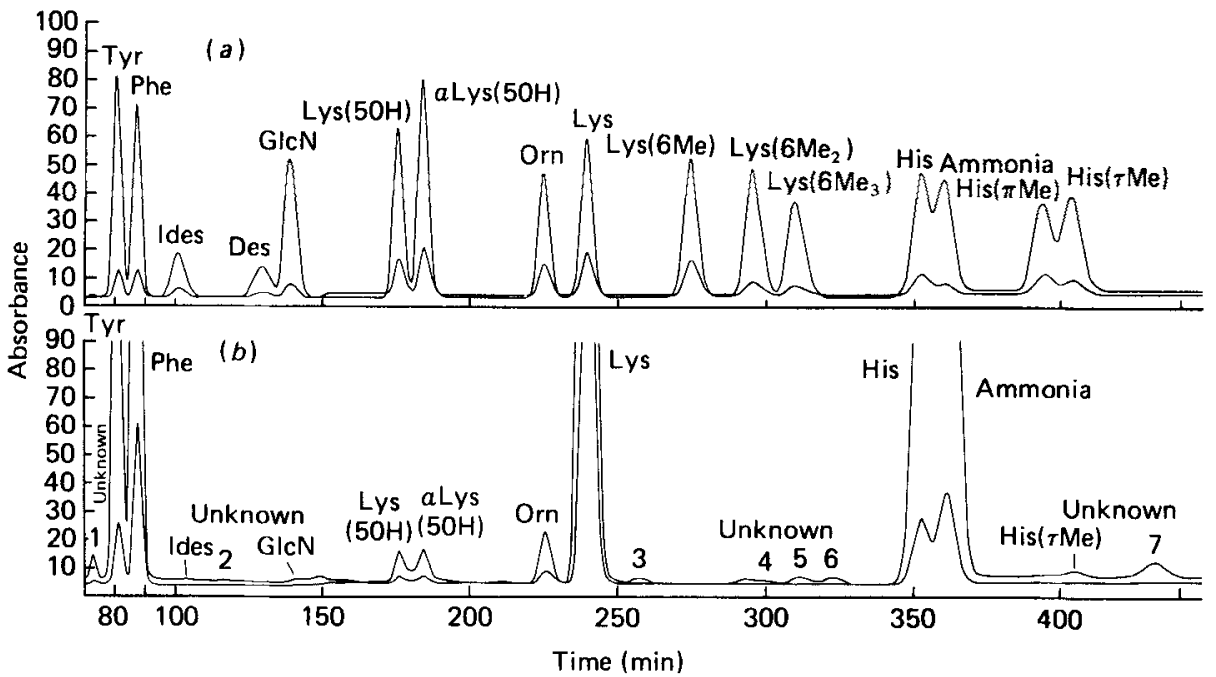

Fig. I. Chromatographic separations of all methylated basic amino acids, the diastereoisomers of 5-hydroxylysine, stable cross-links and related compounds in squid meal (SqM) hydrolysates. (a) Separation of a synthetic amino acid calibration mixture; (b) A typical chromatographic separation of a $96 \mathrm{~h} \mathrm{SqM}$ hydrolysate. The $550 \times 2.8 \mathrm{~mm}$ micro-column packed with Beckman type W-2 resin was operated at $28^{\circ}$ using $0.35 \mathrm{M}$-sodium citrate buffer, $\mathrm{pH} 5.607$, at a flow rate of $4.64 \mathrm{ml} / \mathrm{h}$ and 600 psi ( $4128 \mathrm{kN} / \mathrm{M}^{2}$ ) on a Beckman model I I M fully automated amino acid analyser. The upper curve shows absorbance at $570 \mathrm{~nm}$ and the lower curve absorbance at $440 \mathrm{~nm}$. Des, desmosine; Ides, iso-desmosine; GlcN, glucosamine; Lys $(50 \mathrm{H})$, 5-hydroxylysine; aLys $(50 \mathrm{H})$, allo-5hydroxylysine; Lys(6Me), $\mathrm{N}^{\mathrm{B}}$-methyllysine; Lys $\left(6 \mathrm{Me}_{2}\right), \mathrm{N}^{\mathrm{B}}$-demethyllysine; Lys(6Me3), $\mathrm{N}^{\mathrm{B}}$ trimethyllysine; His $(\tau \mathrm{Me}), \mathrm{N}^{\tau}$-methylhistidine; His $(\pi \mathrm{Me}), \mathrm{N}^{n}$-methylhistidine.

free amino acid occurring at such a high concentration appears to be taurine, which has been shown to be involved in intracellular osmoregulation (Hochachka et al. I975). Table 4 also lists the amounts $(\mathrm{mg} / \mathrm{kg}$ diet) of 4-hydroxyproline, 5-hydroxylysine, isodesmosine and related compounds present.

When the SqM was hydrolysed for the determination of amino acids a small amount of insoluble humin was formed and the acid-hydrolysate was dark in colour. The acid-hydrolysate was filtered to remove the humin and the analysis was carried out on the filtrate (Table 4). The presence of polysaccharide was confirmed by the detection of hexosamines, common constituents of mucopolysaccharides, on the amino acid chromatograms (Fig. I), and also by the detection of a peak of yellow material on the long micro-column of the amino acid separation, indicating the emergence of carbohydrate decomposition products.

The results of amino acid analyses (Table 4 ) indicate that SqM contains a good complement of most, if not all, the amino acids considered essential for poultry. With few exceptions SqM has as high or higher concentration of all of the essential amino acids (EAA) for poultry (Scott et al. I969) as FM (Hubbell, 1977).

The results obtained for mortality, live body-weights, food conversion, and monetary returns when broiler chicks were fed three different levels of SqM are presented in Table 5.

In general the addition of SqM to broiler diets at the three different levels of supplementation (50, 100 and $150 \mathrm{~g} / \mathrm{kg}$ diet) enhanced growth response, and improved significantly $(P<0.05)$ food conversion rates compared to that of control chicks. The improvement of food conversion from adding graded levels of SqM to the diets was linear $(P<0.01)$. The body-weights of both male and female broilers fed on diets containing $150 \mathrm{~g} \mathrm{SqM} / \mathrm{kg}$ were higher than those fed on diets containing 50 or $100 \mathrm{~g} \mathrm{SqM} / \mathrm{kg}$; in general the patterns of the results for both starter and finisher diets were remarkably similar. The improved food 
Table 5. Mortality, body-weights, food conversion and monetary returns of broiler chickens fed on diets containing squid (Illex illecebrosus) meal (SqM)

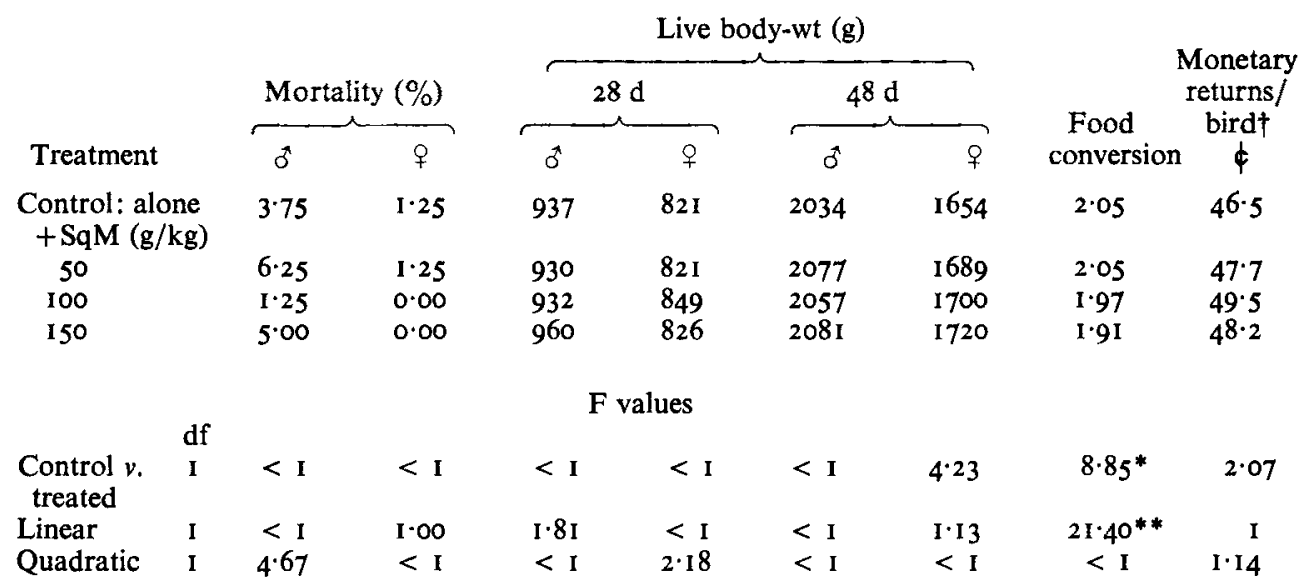

*P<0.05; ** $P<0.01$.

$\dagger$ Monetary returns per bird housed from meat marketed over the cost of feed and chicks.

Table 6. A comparison of the essential amino acid (EAA) requirements for broiler chickens and the amounts of EAA contributed by squid (Illex illecebrosus) meal (SqM) supplementation of broiler diets

\begin{tabular}{|c|c|c|c|c|c|c|}
\hline \multirow{2}{*}{$\mathrm{SqM}$ in $\operatorname{diet}(\mathrm{g} / \mathrm{kg}) \ldots$} & \multicolumn{3}{|c|}{ EAA } & \multirow{2}{*}{$\begin{array}{c}\text { EAA in } \\
\mathrm{SqM} \\
(\mathrm{g} / \mathrm{kg} \\
\text { protein) }\end{array}$} & \multicolumn{2}{|c|}{ Reference EAA requirements* } \\
\hline & 50 & 100 & I 50 & & $\mathrm{~g} / \mathrm{kg}$ diet & $\begin{array}{l}\text { g/kg dietary } \\
\text { protein }\end{array}$ \\
\hline Threonine & $1 \cdot 3$ & 2.5 & $3 \cdot 8$ & 4 I & $5 \cdot 0-5 \cdot 2$ & $28-29$ \\
\hline Glycine & $5 \cdot 2$ & $\begin{array}{r}2.5 \\
10.5\end{array}$ & $\begin{array}{r}30 \\
15.7\end{array}$ & $\begin{array}{r}41 \\
162\end{array}$ & $4 \cdot 8-5 \cdot 0$ & $\begin{array}{l}20-29 \\
27-28\end{array}$ \\
\hline Valine & $1 \cdot 4$ & $2 \cdot 9$ & $4 \cdot 3$ & 44 & $6 \cdot 9-7 \cdot 1$ & $38-39$ \\
\hline $\begin{array}{l}\text { Cystine }+ \\
\text { methionine }\end{array}$ & 0.8 & $1 \cdot 6$ & $2 \cdot 4$ & 26 & $5 \cdot 8$ & 32 \\
\hline Isoleucine & $1 \cdot 0$ & $1 \cdot 9$ & $2 \cdot 9$ & 30 & $<4.8$ & $<27$ \\
\hline Leucine & $1 \cdot 5$ & $3 \cdot I$ & 4.6 & 48 & $<10.5$ & $<5^{8}$ \\
\hline $\begin{array}{l}\text { Tyrosine }+ \\
\text { phenylalanine }\end{array}$ & 0.9 & $1 \cdot 9$ & $2 \cdot 8$ & 29 & $10.9-11.2$ & $<6 I-62$ \\
\hline Lysine & $1 \cdot 3$ & $2 \cdot 5$ & $3 \cdot 8$ & 39 & $8 \cdot 7$ & 48 \\
\hline Histidine & 0.3 & 0.6 & 0.9 & 9 & $<3.4$ & $<19$ \\
\hline Arginine & 0.7 & $1 \cdot 5$ & $2 \cdot 2$ & 23 & $<7.4$ & $<42$ \\
\hline Tryptophan & ND & ND & ND & I $5^{\dagger}$ & $<\mathrm{r} \cdot 4$ & $<7.8$ \\
\hline & & $\begin{array}{l}\mathrm{ND}, \\
* \mathrm{Fr} \\
+\mathrm{Fr}\end{array}$ & rmi & $\begin{array}{l}\text { Deans } \\
\text { 4). }\end{array}$ & & \\
\hline
\end{tabular}

conversion $(P<0.0 \mathrm{I})$ and the relatively low mortality of the chicks fed on SqM, resulted in improved monetary returns compared with that of chicks fed on the control diets. Interestingly, the highest returns occurred with chicks fed on diets supplemented with 100 or I $50 \mathrm{~g} \mathrm{SqM} / \mathrm{kg}$.

Preliminary results of studies conducted to ascertain the effect of SqM supplementation to the diet on the quality and flavour of broiler meat indicate that addition of SqM to broiler diets at the two lower levels of supplementation (50 or $100 \mathrm{~g} \mathrm{SqM} / \mathrm{kg}$ ) did not impart any flavours to fresh or frozen meat regardless of whether the meat was fried, baked or barbecued. Neither was there evidence of flavour-taint in fresh meat from broilers fed on 


\section{0 \\ H. W. Hulan, F. G. Proudfoot and C. G. Zarkadas}

Table 7. A comparison of the essential amino acid $(E A A)$ patterns $(\mathrm{g} / \mathrm{kg}$ of total EAA) of squid (Illex illecebrosus) meal $(S q M)$, casein $(C S)$, soya-bean meal $\left(S B{ }_{-45}\right)$ and whole-egg protein $(W E P)$

$\quad$ EAA
Phenylalanine
Isoleucine
Leucine
Lysine
Methionine + cystine
Valine
Threonine
Tyrosine
Tryptophan $\ddagger$
EAA index $\$$

$\begin{array}{rr}\text { SqM } & \text { CS* } \\ 50 & \text { I02 } \\ 93 & \text { I I I } \\ \text { I49 } & 232 \\ \text { I22 } & 159 \\ 43 & 72 \\ \text { I40 } & 127 \\ \text { I28 } & 83 \\ 41 & 66 \\ 47 \ddagger & 39 \\ 74 \cdot 5 & 87 \cdot 1\end{array}$

SB- $4{ }^{*}$
133
166
191
153
81
128
95
77
26
$78 \cdot 5$

WEP
114
129
172
125
107
141
99
81
31
100

* From Drouliscos (1976).

$\dagger$ From FAO/WHO (1965).

$\ddagger$ From Lee et al. (1974).

$\S$ Calculated as described by Oser (195I).

a diet having the highest level of SqM supplementation ( $150 \mathrm{~g} \mathrm{SqM} / \mathrm{kg}$ ). There was some indication that flavour development can occur in broilers fed on a diet containing the highest level of SqM supplementation ( $150 \mathrm{~g} / \mathrm{kg}$ diet) after the meat had been stored frozen for I month or longer. Further studies are currently being carried out to clarify such a possibility.

\section{DISCUSSION}

Unlike fish where the portion suitable for human consumption is roughly $40-70 \%$ (Takahashi, 1965), the edible portion in the squid is as large as $80 \%$ (mantle $50 \%$, arms and tentacles, $30 \%$ ).

Ward \& Wainwright (1972) and Moon \& Hulbert (1975) have provided information on the unique obliquely striated musculature of the squid which consists mainly of circular and radial myofibrils arranged in alternating rings along the length of the mantle, sarcoplasmic proteins and connective tissue fibres supporting the body structures. Lee et al. (1974) have recently carried out a limited number of mice-feeding tests using squid protein concentrates that were spray-dried at different temperatures. They claimed that the adjusted protein efficiency ratio (body-weight gain : crude protein intake; PER) of the squid protein concentrates was higher $(2 \cdot 66-3 \cdot 08)$ than that of the reference casein protein (2.50) diet. Similar nutritional studies by Varela et al. (1962) have shown that the biological value of squid was 0.82 compared to 0.837 and 0.748 for octopus (Octopus vulgaris) and shrimp (Parapenocas longirostris) respectively.

The results presented herein provide evidence that properly processed SqM can be a good source of high-quality dietary protein for the broiler chicken. It is apparent that its inclusion in both starter and finisher diets at the rate of $100 \mathrm{~g} / \mathrm{kg}$ diet results in optimum biological response, monetary returns and the absence of tainted flavour in the meat produced. SqM contained an average of $645 \mathrm{~g}$ crude protein $/ \mathrm{kg}$ and can be considered a good supplement for replacing more expensive protein concentrates in broiler chicken diets. The finding that it can produce the same or better complementary effects (compared with FM) with cereal proteins for promoting growth in broiler chickens (Table 5) is also very encouraging.

A comparison between the EAA profile ( $\mathrm{g} / \mathrm{kg}$ dietary protein) of SqM and EAA requirements as recommended by Woodham \& Deans (1975) for broiler chickens, indicated that SqM was limited with respect to lysine, methionine and cysteine (Table 6). Supplementing 
the diets with $0.45 \mathrm{~g}$ DL-methionine $/ \mathrm{kg}$ (Table I) effectively increased the methionine and therefore the total sulphur-containing amino acids of the diets (Table 6). Although the remaining EAA in SqM (Table 6) were present at levels that were closer to those recommended by Woodham \& Deans (1975), marked complementary effects were noted when $100 \mathrm{~g}$ and $150 \mathrm{~g} \mathrm{SqM} / \mathrm{kg}$ diet were mixed with SB or cereals in the diets (Table 5). Moreover, when comparisons of the EAA profiles of SqM were made $(\mathrm{g} / \mathrm{kg} \mathrm{N})$ with other protein concentrates (Table 7) it was found that SqM was higher than that of SB but lower than those of casein (Drouliscos, 1976) and whole-egg protein (FAO/WHO, 1965). Similar results were obtained from the EAA indices calculated from the amino acid composition of SqM (Table 4) by the method of Oser (195I).

Although these predictive tests are based on the analysis of crude protein hydrolysates which afford a valuable guide in compounding the protein mixtures in poultry nutrition, they fail to take into account differences in the digestibility, the quality of the various proteins present and the availability of individual amino acids. Because of this Woodham \& Deans (1977) and Woodham \& Clarke (1977) have recently demonstrated that neither chemical score nor EAA index values calculated from the known amino acid composition of dietary supplements could be used to accurately predict quality under either practical or experimental chick or rat growth conditions.

The chemical approach used in this study for evaluating the protein quality of SqM was based on the direct determination of its collagen, elastin and skeletal muscle contents since the contribution of these proteins to the over-all nutritive value and amino acid availability differ considerably (Oser, 1951). In this approach collagen is determined from the amounts of the characteristic basic amino acids 5-hydroxylysine and 4-hydroxyproline found in $\mathrm{SqM}$ protein hydrolysates (Eastoe, 1967) and elastin is calculated from the amounts of isodesmosine and desmosine present (Partridge \& Keeley, 1973). Both determinations are carried out from a single analysis of SqM hydrolysates by either the manual or the accelerated chromatographic methods of Zarkadas (1975) and C. G. Zarkadas (unpublished results).

The chromatograms illustrated in Fig. I are typical of the separations obtained by the accelerated system (Zarkadas, unpublished results). Good separations from a standard containing all the unique basic amino acids likely to be encountered in a biological system were obtained (Fig. I $a$ ). As may be seen in Fig. I $(b)$ the analysis of SqM hydrolysates by this method revealed the complete separation of the diastereoisomers of 5 -hydroxylysine and small amounts of isodesmosine along with two major (nos. I and 7) and five minor (nos. 2-6) as yet unidentified stable components. The accurate determination of 5-hydroxylysine content can be made from the sum of the values obtained for the diastereoisomers after epimerization (Zarkadas, I975). It should also be pointed out that in SqM hydrolysates only small amounts of $\mathrm{N}^{6}$-methyllysine and $\mathrm{N}^{7}$-methylhistidine are present (Table 4 ) compared to the methylated basic amino acid content of mammalian muscle tissue (Vickery, 1972; Paik \& Kim, 1975).

Although collagen has been found in most of the invertebrate phyla (Eastoe, 1967) only limited chemical studies have been done on the collagen and myofibrillar proteins of the squid (Ward \& Wainwright, 1972). Pikkarainen \& Kulonen (1969) provided some information on the hydroxy and acidic amino acid content of the Illex $\mathrm{sp}$. and have shown that only $7.9 \mathrm{~g} \mathrm{4}$-hydroxyproline/ $\mathrm{kg}$ occurs in squid mantle collagen (Pikkarainen et al. 1968) which corresponds to $21 \mathrm{~mol} 4$-hydroxyproline $\left(7.9 \mathrm{~g}\right.$ hydroxyproline $/ \mathrm{kg}$ collagen; I I $3 . \mathrm{I}_{3}$ anhydrous molecular weight $\times 3000=20.95 \mathrm{~mol}$ ) $/ \mathrm{mol}$ collagen (molecular weight 300000 ; Cain I970; Hulmes et al. 1973). The mean values obtained in the present study for the value 4-hydroxyproline : 5-hydroxylysine of SqM were found to be $6: \mathrm{I}$. These results are in reasonable agreement with those values reported for collagen of other invertebrates by 


\section{H. W. Hulan, F. G. Proudfoot and C. G. Zarkadas}

Cain (I970), Nordwig \& Hayduk (1969) and Hunt et al. (1970), but much lower than those found for collagen of land mammals (Eastoe, 1967). Thus from the amounts of 4-hydroxyproline reported in Table $4(429.9 \mathrm{mg} / \mathrm{kg}$ diet $)$ it was calculated that the whole squid, processed as meal, contains $52.0 \mathrm{~g}$ collagen $/ \mathrm{kg}$ as given by the expression:

amount of unusual amino acid in $\mathrm{SqM}(\%)$

amount of the same amino acid in squid collagen (\%) $\times$ molecular weight of collagen.

The result obtained from the 5 -hydroxylysine content of SqM was $52 \cdot 3 \mathrm{~g}$ collagen $/ \mathrm{kg}$ diet. Similarly, the amount of elastin (molecular weight 74000 with 2 mol isodesmosine $/ \mathrm{mol}$ elastin; Partridge \& Keeley, I973) present in SqM (0.I I g/ kg diet) was calculated from its iso-desmosine content. Therefore, when the amount of connective tissue $\mathrm{N}(9 \cdot 6 \mathrm{~g} / \mathrm{kg}$ diet) was subtracted from the total $\mathrm{N}$ determined in SqM ( $103.2 \mathrm{~g} / \mathrm{kg}$ diet, Table 4$)$, the difference $(93.6 \mathrm{~g} / \mathrm{kg}$ diet) represents the amount of high-quality skeletal muscle protein present in the squid. However, corrections for non-protein- $N$ must also be made. When the amino acid composition and sequence of squid collagen or elastin is known, the amounts of EAA contributed by skeletal muscle proteins can also be calculated. This approach has the additional advantage that it can be applied to the determination of the connective tissue content of fresh or processed SqM proteins as well as that of fish, meat and bone meals supplied as nutritional supplements.

The authors acknowledge Dr K. McRae for his advice and statistical analyses; Maritime Co-op Services, Moncton, New Brunswick, for providing the squid meal used in these studies; Dr Ian Sibbald and Dr J. K. Kramer, Animal Research Institute, Ottawa, for conducting the true metabolizable energy assay and lipid analyses respectively; Analytical Chemistry Services, Agriculture Canada, for the use of the amino acid analysers; the skilful technical assistance of Mr D. Tutte.

\section{REFERENCES}

Association of Official Agricultural Chemists (1975). Official Methods of Analysis, I2th ed. Washington, DC: Association of Official Agricultural Chemists.

Beckman Instruments Inc. (1976). Methodology Bulletin no. I 2 I M-A-TB-063. Palo Alto, Calif.

Beckman Instruments Inc. (1976). Methodology Bulletin no. I2I M-TB-004. Palo Alto, Calif.

Beckman Instruments Inc. (1976). Methodology Bulletin no. AA-TB-ooI-0I4. Palo Alto, Calif.

Bligh, E. G. \& Dyer, W. J. (1959). Can. J. Biochem. Physiol. 37, 911.

Cain, G. D. (1970). Archs Biochem. Biophys. 141, 264.

Christie, W. W. (1973). Lipid Analysis. Oxford: Pergamon Press.

Clarke, M. (1966). Adv. mar. Biol. 4, 91.

Crampton, E. W. (1956). Applied Animal Nutrition. San Francisco: W. H. Freeman.

Drouliscos, N. J. (1976). Br. J. Nutr. 36, 449.

Eastoe, J. E. (1967). In Treatise on Collagen, vol. I, p. I [G. N. Ramocchandran, editor]. New York: Academic Press.

FAO/WHO (1965). Tech. Rep. Ser. Wld Hlth Org. no. 301.

Hidiroglou, M. \& Zarkadas, C. G. (1976). Can. J. Physiol. Pharmac. 54, 336.

Hochachka, P. W., Moon, T. W., Mustafa, T. \& Storey, K. B. (1975). Comp. Biochem. Physiol. 52 B, 15 I. Hubbell, C. R. (1977). Feedstuffs 49, 16.

Hulan, H. W., Hunsaker, W. G., Kramer, J. K. G. \& Mahadevan, S. (I976). Can. J. Physiol. Pharmac. 54, I. Hulmes, D. J., Miller, A., Parry, D. A. D., Piez, K. A. \& Woodhead-Galloway, J. (1973). J. molec. Biol. 79, 137.

Hunt, S., Grant, M. E. \& Liebovich, S. J. (1970). Experientia 26, 1204.

Lee, C. M., Toledo, R. T., Nakayama, T. O. M. \& Chichester, C. O. (1974). J. Fd Sci. 39, 735.

Moon, T. W. \& Hulbert, W. C. (1975). Comp. Biochem. Physiol. 52 B, 145.

Moore, S. (1963). J. biol. Chem. 238, 235.

Moore, S. \& Stein, W. H. (1963). Meths Enzym. 6, 819.

Nordwig, A. \& Hayduk, U. (I969). J. molec. Biol. 44, $16 \mathrm{I}$.

Oser, B. L. (I 95I). J. Am. diet. Assoc. 27, 396.

Paik, W. K. \& Kim, S. (1975). In Advances in Enzymology, vol. 42, p. 227 [A. Meister, editor]. New York: Interscience, John Wiley and Sons Inc. 
Partridge, S. M. \& Keeley, F. W. (1973). In Advances in Experimental Medicine and Biology, vol. 43, p. 173 [W. D. Wagner and T. B. Clarkson, editors]. New York: Plenum Press.

Pikkarainen, J. \& Kulonen, E. (1969). Nature, Lond. 223, 839.

Pikkarainen, J., Rontanen, J., Vastamaki, M., Laupiaho, K., Kari, A. \& Kulonen, E. (I968). Eur. J. Biochem. 4, 555.

Scott, M. L., Nesheim, M. G. \& Young, R. J. (1969). Nutrition of the Chicken. Ithaca, New York: M. L. Scott and Associates.

Sibbald, I. R. (1976). Poult. Sci. 55, 303.

Steel, R. G. D. \& Torrie, J. H. (1960). Principles and Procedures of Statistics. New York: McGraw-Hill.

Takahashi, T. (1965). In Fish as Food, vol, 4, p. 339 [G. Borgstrom, editor]. New York and London: Academic Press.

Templeman, W. (I966). Tech. Bull. J. Fish. Res. Bd. Can. no. 454, I 22.

Varela, G., Pujol, A. \& Moreiras, O. (1962). Fish in Nutrition, p. 259. London: Fishing News Ltd.

Vickery, H. B. (1972). In Advances in Protein Chemistry, vol. 26, p. 81 IC. B. Anfinsen Jr, J. T. Edsall and F. M. Richards, editors]. New York: Academic Press.

Ward, D. V. \& Wainwright, S. A. (1972). J. Zool., Lond, 167, 437.

Woodham, A. A. \& Clarke, E. M. W. (1977). Br. J. Nutr. 37, 309.

Woodham, A. A. \& Deans, P. S. (1975). Br. Poult. Sci. 16, 269.

Woodham, A. A. \& Deans, P. S. (I977). Br. J. Nutr. 37, 289.

Zarkadas, C. G. (1975). Can. J. Biochem. 53, 96. 